УДК 612.82.062:57.04+57.084.1

О. 3. Мельнікова, В. П. Ляшенко, Т. Г. Чаус, Д. О. Бурцева, Л. В. Калюжна

Запорізький державний медичний університет

Дніпропетровський національний університет ім. Олеся Гончара

\title{
ЗМІНИ СУМАРНОЇ ФОНОВОЇ ЕЛЕКТРИЧНОЇ АКТИВНОСТІ ГІПОКАМПА ТА ПОВЕДІНКОВИХ РЕАКЦІЙ ЩУРІВ ПРИ ТРИВАЛОМУ СТРЕСІ
}

Досліджено динаміку потужностей і спектральну композицію хвиль сумарної фонової електричної активності гіпокампа та зміни рухової та дослідницької активності щурів протягом тривалого стресу. Виявлено залежність модуляції аналізованих показників від тривалості стресового впливу, встановлено кореляційні зв'язки між параметрами біоелектричної активності гіпокампа та поведінковими реакціями щурів.

О. З. Мельникова, В. П. Ляшенко, Т. Г. Чаус, Д. А. Бурцева, Л. В. Калюжная

Запорожский государственный медицинский университет

Днепропетровский национальный университет им. Олеся Гончара

\section{ИЗМЕНЕНИЯ СУММАРНОЙ ФОНОВОЙ ЭЛЕКТРИЧЕСКОЙ АКТИВНОСТИ ГИПОКАМПА И ПОВЕДЕНЧЕСКИХ РЕАКЦИЙ КРЫС ПРИ ДЛИТЕЛЬНОМ СТРЕССЕ}

\begin{abstract}
Исследовали динамику мощностей и спектральную композицию волн сумарной фоновой электрической активности гиппокампа и изменения двигательной и исследовательской активности крыс во время длительного стресса. Выявлена зависимость модуляции анализируемых показателей от длительности стрессового влияния, установлены корреляционные связи между параметрами биоэлектрической активности гиппокампа и поведенческими реакциями крыс.
\end{abstract}

O. Z. Melnikova, V. P. Lyashenko, T. G. Chaus, D. A. Burceva, L. V. Kalyuzhnaya

Zaporizhzha State Medical University, Oles' Honchar Dnipropetrovsk National University

\section{CHANGES OF TOTAL BACKGROUND ELECTRICAL ACTIVITY OF HYPPOCAMPUS AND BEHAVIOURAL REACTIONS OF RATS DURING LONG-LASTING STRESS}

The dynamics of power and waves spectral composition of total background electrical activity in hippocampus and changes of motor and investigative activity of rats during long-lasting stress were investigated. The dependence of analysed indices on duration of the stress influence was found. The correlation between hippocampus bioelectrical activity and behavioural reactions of rats were established.

Вступ

Відомо, що стрес-реакція організму здійснюється під контролем центральних структур головного мозку та регулюється ними [2; 3; 6-8]. Серед них важлива роль 
належить гіпокампу, який бере участь в організації та регуляції емоційно-мотиваційних процесів, у механізмах вегетовісцерального та нейроендокринного забезпечення адаптивної поведінки, у формуванні, активації та енергетичному забезпеченні вищих функцій мозку, пов'язаних із пам'яттю, навчанням, мисленням [7; 13-15].

Під впливом різних стресорів відбуваються зміни сумарної фонової електричної активності гіпокампа, в якій відображується взаємодія збуджувальних і гальмівних процесів, що ініціюють у центральних структурах стресогенні умови [2-4; 12]. Указані зміни мають певні особливості протягом різних стадій стресу, відображуючи модуляцію гормонально-медіаторних впливів на нейрони мозку [4]. Це може зумовлювати складну динаміку різних компонентів цілісної стрес-відповіді організму, одним з яких слугує поведінка живих істот у стресогенних умовах [2; 9], зокрема їх рухова та дослідницька активність. Однак взаємозв'язок між характером змін фонового електрогенезу гіпокампа та вказаними показниками поведінки залишається не до кінця з'ясованим.

Тому мета нашого дослідження - виявити вплив тривалого стресу на параметри електрогіпокампограми (ЕГпГ) щурів, встановити зв'язок між ними та поведінковими реакціями щурів.

\section{Матеріал і методи досліджень}

Експерименти здійснювали на нелінійних білих щурах-самцях відповідно до існуючих міжнародних вимог і норм гуманного ставлення до тварин. На початку дослідження щури мали вагу 125-140 г. Їм створювали загальноприйняті санітарногігієнічні умови, раціон і режим пиття [5]. Контрольних тварин $(n=24)$ утримували в стандартних умовах протягом усього експерименту. Щурам другої групи $(n=21)$ протягом 21-го тижня створювали стресову зооконфліктну ситуацію шляхом обмеження життєвого простору до 80-100 см² на одну особину. Для цього до стандартної клітки розміром $0,3 \times 0,5$ м, де повинно утримуватись 2-3 тварини, розміщували 20-22 щури.

Тестування поведінкових реакцій щурів проводили за методикою «відкритого поля». Для цього використовували незакриту зверху пластикову камеру розміром $80 \times 80 \times 40$, дно якої було розграфлено на 25 квадратів. Дотримувались загальноприйнятих правил тестування тварин у «відкритому полі» [1].

На початку досліду тварину розміщували в центрі відкритого поля, а потім підраховували число відвіданих нею квадратів (показник горизонтальної рухової активності) і число відвіданих нею центральних квадратів (характеристика дослідницької активності) [1]. Квадратики вважали перетнутими, якщо тварина своїм тулубом (як мінімум, однією з лап) пересікала яку-небудь 3 його сторін. Тестування тривало 3 хвилини. Дослідження поведінкових реакцій кожної тварини проводили двічі на день протягом трьох діб перед тим як забрати ії в гострий експеримент для реєстрації ЕГпГ.

Відведення ЕГпГ проводили у підгрупах із трьох тварин, відібраних із контрольної та стресової груп через кожні три тижні впродовж усього періоду дослідження (як згадувалось вище - 21 тиждень). Хірургічна підготовка до відведення ЕГпГ виконувалась після внутрішньочеревинного введення 20 мг/кг кетаміну та 50 мг/кг тіопенталу натрію. Після фіксації тварини у стереотаксичному приладі та проведення трепанації черепа в гіпокамп уводили уніполярний електрод (ніхром, діаметр 100 мкм) згідно 3 координатами: bregma $(B)-1,4$, латеральна вісь $(L)-0,8$, інтерауральна вісь $(I)-4,0$ [10]. Референтний електрод закріплювали на вушній раковині тварини. Верифікацію локалізації кінчиків електродів проводили на фронтальних зрізах мозку. 
ЕГпГ реєстрували за допомогою стандартного комплексу електрофізіологічного устаткування. Запис ЕГпГ починали, коли в електричній активності зникали наркотичні веретена. Із гіпокампа кожної тварини робили по 10-12 записів тривалістю 1-2 хвилини, які у цифровому вигляді запам'ятовували, зберігали у комп'ютері та здійснювали їх подальшу обробку за допомогою пакета прикладних програм у складі «MathCAD 2000». Аналізували спектральні потужності $\left(\right.$ мкB $\left.^{2}\right)$ і нормовані потужності (\%) хвиль ЕГпГ у межах загальноприйнятих частотних діапазонів [3].

Отримані результати по кожній підгрупі тварин у відповідні тижні дослідження обробляли статистично з визначенням середніх і їх помилок. Крім того, розраховували коефіцієнти кореляції (та їх похибки) між характеристиками ЕГпГ усіх частотних діапазонів і показниками рухової та дослідницької активності тварин. Міжгрупові відмінності оцінювали, використовуючи $t$-критерій Стьюдента. Результати вважали достовірними при рівні значимості $p<0,05$.

\section{Результати та їх обговорення}

У змінах показників ЕГпГ під впливом тривалого стресу можна виділити декілька фаз (рис. 1). Протягом першої з них, що тривала від 3-го до 6-го тижнів, у тварин стресової групи відбувалось зменшення потужностей і спектральних потужностей хвиль у частотних діапазонах 4-8 і 8-14 Гц. При цьому такі показники для хвиль частотою 14-30 Гц збільшувались, а у діапазоні 0,5-4 Гц зростала тільки спектральна потужність коливань.

Із 9-го до 12-го тижня експерименту під впливом стресогенних умов відбувалось збільшення потужностей хвиль усіх частотних діапазонів (крім 14-30 Гц на 9-му тижні), що супроводжувалось зростанням спектральної потужності хвиль середньочастотних діапазонів. Однак до 15-го тижня експерименту потужність усіх хвиль в ЕГпГ щурів стресової групи істотно зменшувалась відносно контролю, хоча зміни спектральної потужності хвиль були подібними до попереднього періоду. Це явище спостерігалось до 18-го тижня дослідження, однак зменшення потужності хвиль, в основному, було недостовірним, а зміни спектральних потужностей хвиль ще більше зростали. До 21-го тижня стресового впливу останні майже не відрізнялись від контрольних значень, однак в ЕГтГ тварин стресової групи зменшилась частка високочастотних хвиль. Крім того, в електричній активності гіпокампа щурів у цей період відбулось зростання потужностей хвиль усіх частотних діапазонів.

У складній динаміці змін параметрів ЕГтГ тварин стресової групи порівняно 3 контролем могли відображуватися різні стадії стрес-реакції організму. Упродовж них відбувається суттєва модуляція медіаторно-гормональних впливів на нейрони [10], внаслідок чого може змінюватись баланс процесів збудження та гальмування у центральних структурах, залучених до контролю цілісної стрес-відповіді. Такі процеси зумовлюють постсинаптичні потенціали, які сумуються та реєструються у фоновій сумарній електричній активності гіпокампа. Відомо, що збалансованому співвідношенню збудження та гальмування відповідає збільшення потужності хвиль фонової сумарної електричної активності мозку [3; 7], яке в наших експериментах спостерігалось 3 9-го по 12-й тиждень стресового впливу. Очевидно, у цей період збільшення процесів збудження у гіпокампі, про яке свідчило зростання відсотка високочастотних хвиль, викликало активацію стрес-лімітувальних систем мозку. Збільшення потужностей хвиль електричної активності відображє адаптований стан організму [6]. Однак наступне їх зменшення через 15-18 тижнів експерименту, очевидно, може свідчити про поступовий перехід стрес-реакції до стадії виснаження, що може бути зумовлено як 90 
недостатньою спроможністю збуджувальних і гальмівних медіаторних систем мозку. До 21-го тижня дослідження потужність хвиль ЕГпГ тварин стресової групи зростала, що може відображати відновлення активності цих систем. Однак це відбувалося на фоні зменшення високочастотної складової спектральної композиції та відсутності у стресованих тварин змін відсотка хвиль у діапазоні 4-8 Гц, які є індикаторами функціональної активності гіпокампа [14]. Це може свідчити про інший механізм зростання потужності хвиль ЕГпГ щурів під впливом стресу у цей період спостереження, ніж на 9-12-му тижнях.
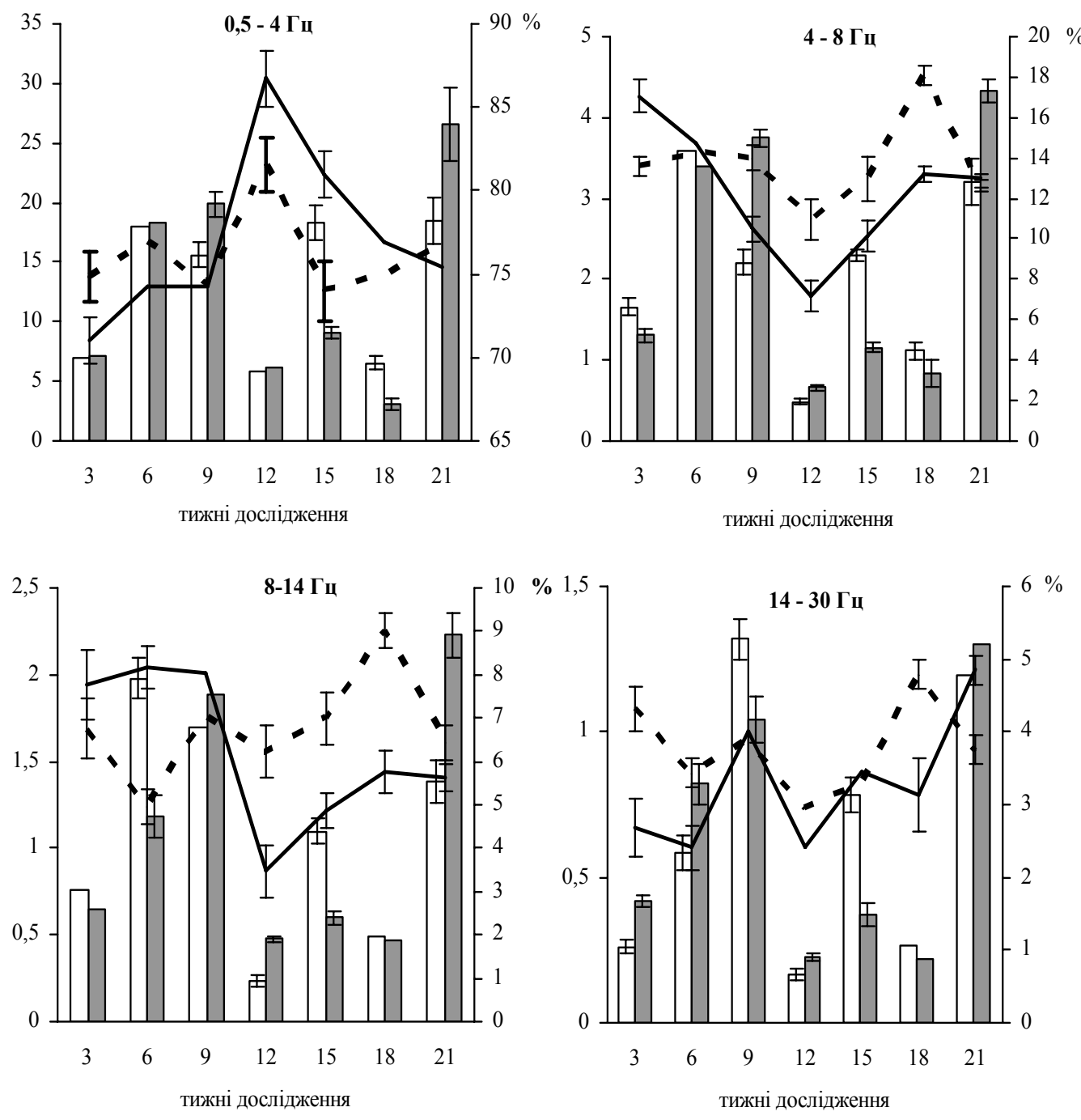

Рис. 1. Вплив тривалого стресу на показники ЕГпГ щурів: ліва вісь ординат - потужності хвиль ЕГпГ відносно початкових значень (умовні одиниці) у тварин контрольної (білі стовпчики) та стресової (сірі стовпчики) групп, права вісь ординат - спектральні потужності хвиль ЕГпГ (\%) тварин контрольної (безперервна лінія) та стресової (пунктирна лінія) груп; вертикальними рисочками позначені помилки середніх у випадку достовірної різниці між групами

Для з'ясування проявів змін фонової електричної активності гіпокампа при тривалому стресі у цілісній стресс-відповіді організму здійснювали аналіз поведінкових 
реакцій тварин. Результати дослідження рухової иа дослідницької активності у тварин контрольної та стресової групи наведені на рисунку 2.

$A$

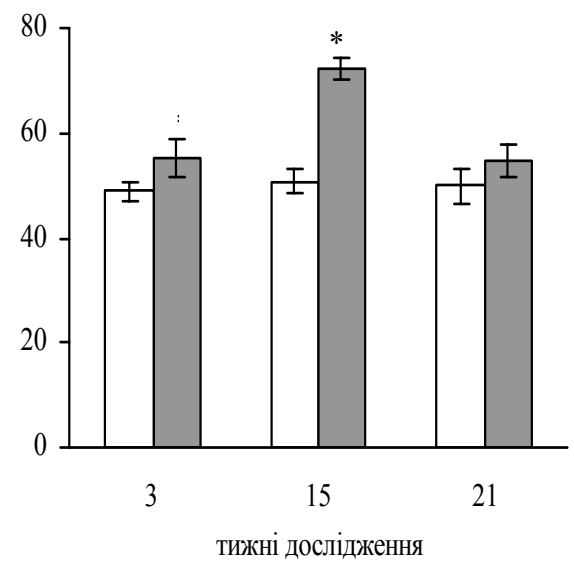

Б

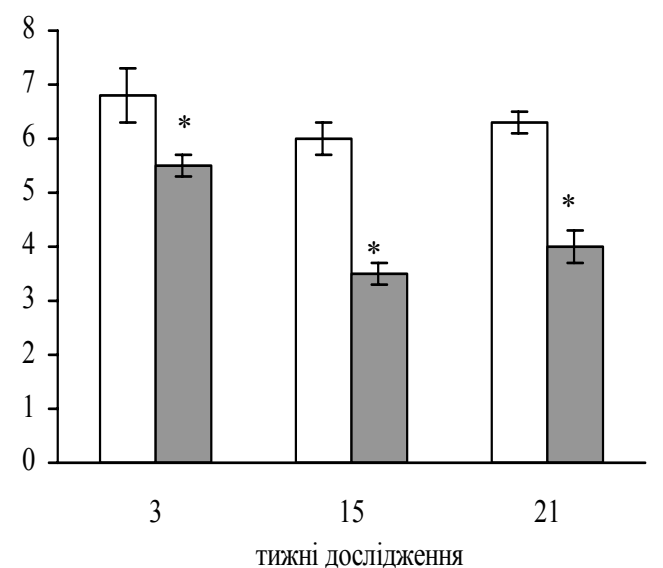

Рис. 2. Показники рухової $(A)$ та дослідницької $($ b) активності тварин контрольної (білі стовпчики) та стресової (сірі стовпчики) груп протягом експерименту: *-достовірні зміни при $p<0,05$

Як видно 3 наведених даних, під впливом тривалого стресу відбувалось збільшення рухової активності тварин протягом усього терміну спостереження. Воно було максимально вираженим на 15-му тижні дослідження, тобто впродовж другої стадії стрес-реакції. До 21-го тижня рухова активність зберігалась збільшеною, але достовірної різниці між цим показником у тварин контрольної та стресової груп не спостерігалось. На відміну від цього, дослідницька активність під впливом стресу достовірно зменшувалась протягом усього експерименту.

Кореляційний аналіз показав, що між потужностями хвиль середньочастотних діапазонів (4-8 і 8-14 Гц) ЕГпГ тварин контрольної групи та їх руховою активністю існували достовірні негативні зв'язки середньої сили ( $r$ складав близько $-0,4)$. Між потужностями хвиль низько- та високочастотного діапазонів і руховою активністю кореляційних зв'язків не виявлено. При стресовому впливі коефіцієнти кореляції між потужністю хвиль ЕГпГ і локомоторною активністю тварин збільшувались, не змінюючи знака ( $r$ становив від $-0,5$ до $-0,6)$, причому вони проявлялись у всіх частотних діапазонах.

Між нормованою потужністю хвиль ЕГпГ у діапазоні від 0,5 до 14 Гц і руховою активністю тварин контрольної групи виявлено достовірні сильні зв'язки (від 0,7$)$ : негативні для середньочастотних хвиль і позитивні для активності у низькочастотному діапазоні. Між нормованою потужністю високочастотних хвиль і руховою активністю щурів зареєстровано слабкий позитивний зв'язок. При стресовому впливі сила всіх указаних зв'язків зменшувалась. Тільки у високочастотному діапазоні він ставав негативним.

Потужності хвиль ЕГпГ тварин і показники їх дослідницької активності в контрольних тварин пов'язувались слабкою кореляцією, а між нормованими потужностями хвиль і дослідницькою активністю існували зв'язки середньої сили: негативні для низькочастотних хвиль і позитивні для хвиль середніх частот. У тварин стресової групи кореляційні зв'язки між потужностями хвиль ЕГпГ і дослідницькою активністю тварин майже не відрізнялись від контролю, а сила кореляції між нормованими потуж- 
ностями хвиль ЕГпГ і аналізованим поведінковим показником збільшувалась для хвиль усіх частотних діапазонів, крім 14-30 Гц, до значень, характерних для сильної кореляції $(0,70-0,81)$.

Таким чином, у ході роботи виявлено зміни характеристик ЕГпГ щурів під впливом тривалого стресу та модуляції їх поведінкових реакцій. Привертає увагу той факт, що останні більшою мірою корелювали 3 нормованими потужностями хвиль. При стресовому впливі сила цих зв’язків змінювалась реципрокно: між нормованими потужностями та руховою активністю зменшувалась, а між аналізованим показником ЕГпГ і дослідницькою активністю - збільшувалась. При цьому як у контролі, так і при стресовому впливі рухова активність мала негативний зв'язок із відсотком середньочастотних хвиль, і позитивний - із представленістю хвиль низької частоти, а коефіцієнти кореляції дослідницької активності для хвиль вказаних діапазонів мали протилежні знаки. Все це певною мірою пояснює різноспрямовані зміни досліджених показників поведінкових реакцій під впливом тривалого стресу, однак це питання потребує подальших досліджень.

\section{Висновки}

При тривалому стресі виявлено зміни сумарної фонової електричної активності гіпокампа, динаміка яких могла відповідати різним стадіям стрес-реакції організму. Вказані зміни могли відображати процеси у мозку та організмі тварин, які призводили до модуляції їх рухової та дослідницької активності, про що свідчать результати кореляційного аналізу між показниками фонової електричної активності гіпокампа та характеристиками поведінкових реакцій.

\section{Бібліографічні посилання}

1. Буреш Я. Методики и основные эксперименты по изучению мозга и поведения / Я. Буреш, О. Бурешова, Д. П. Хьюстон. - М. : Высш. шк., 1991. - 399 с.

2. Ведяев Ф. П. Модели и механизмы эмоциональных стрессов / Ф. П. Ведяев, Т. М. Воробьева. К. : Здоров'я, 1983. - 136 с.

3. Воробьева Т. М. Электрическая активность мозга (природа, механизмы, функциональное значение) / Т. М. Воробьева, С. П. Колядко // Экспериментальная и клиническая медицина. 2007. - № 2. - С. 4-11.

4. Зміни динаміки показників фонової сумарної електричної активності гіпокампа наркотизованих шурів за умов довготривалого стресу і застосування на його тлі модуляторів синаптичної передачі / С. М. Лукашов, Г. Г. Сидоренко, О. З. Мельнікова и др. // Нейрофизиология. - 2009. T. 41, № 4. - C. 316-326.

5. Лабораторные животные: разведение, содержание, использование в эксперименте / И. П. Западнюк, Е. А. Западнюк, Е. А. Захария и др. - К. : Вища школа, 1983. - 383 с.

6. Меерсон Ф. З. Адаптация, стресс и профилактика. - М. : Наука, 1981. - 278 с.

7. Мозг: теоретические и клинические аспекты / Ред. В. Н. Покровский. - М. : Медицина, 2003. $-536 \mathrm{c}$.

8. Пшенникова М. Г. Врожденная эффективность стресс-лимитирующих систем как фактор устойчивости к стрессорным повреждениям // Успехи физиологических наук. - 2003. - Т. 34, № 3. - C. 55-67.

9. Пшенникова М. Г. Феномен стресса // Патологическая физиология и экспериментальная терапия. -2000 . - № 2. - С. 24-31.

10. Стабильные гомеостатические константы и эндокринный статус при хроническом нейрогенном стрессе и стресспротекторных воздействиях / Г. Е. Данилов, И. Г. Брыдина, Л. С. Исакова и др. // Арх. клин. и эксперим. медицины. - 2000. - Т. 9, № 1. - С. 71-74. 
11. Стереотаксический атлас мозга крыс (фронтальные сечения) / Под ред. А. Ю. Буданцева. Пущино : Аналитическая микроскопия, 2002.

12. Шеверева В. М. Особенности формирования и обратимости эмоциональных нарушений у крыс при нейрогенном стрессе // Нейрофизиология. - 2003. - Т. 35, № 2. - С. 147-158.

13. Altman J. The hippocampus and behavioral maturation / J. Altman, R. L. Brunner, S. A. Bayer // Behav. Biol. - 1993. - Vol. 8. - P. 557.

14. Buzsaki G. Theta oscillations in the hippocampus // Neuron. - 2002. - Vol. 33. - P. 325-340.

15. Sutherland R. J. Configural association theory: The role hippocampal formation in learning, memory and amnesia / R. J. Sutherland, J. W. Ruby // The Journal of Comparative Neurology. 2003. - Vol. 47. - P. 455-463.

Надійшла до редколегї 30.01.2011 